\title{
ISOLATION AND PARTIAL CHARACTERIZATION OF A GLYCOPEPTIDE FROM CERUMEN
}

\author{
HIROSHI MASUDA, SHIGEKI SHICHIJO, TOMOYOSHI GOYA \\ AND MUTSUYA TAKEUCHI \\ Institute of Clinical Pathology, Kurume University School \\ of Medicine, Kurume, 830, Japan
}

Received for publication June 26, 1978

\begin{abstract}
A glycopeptide was isolated from cerumen and was assayed by determining the carbohydrate content of material which remained after proteolysis. The component consisted of hexose, peptide, galactosamine, sialic acid, sulfate and glucosamine; hexose and peptide were main components. The separation posessed galactose and glucose as major hexose components.
\end{abstract}

\section{INTRODUCTION}

Glycopeptide and glycosaminoglycans in skin and inner ear have well been studied by many authors (Tanaka, 1967 ; Saito and Daly, 1970). At present, however, little is known about these substances in external auditory meatus. In this paper it was attempted to isolate and characterize the glycopeptide from the cerumen.

\section{MATERIALS AND METHODS}

\section{Materials}

Normal cerumen samples were obtained from fifty subjects of both sexes aged between 16 and 55 years old. All materials were stored in a deep freezer until further processed. The samples were put into several changes of acetone for several days, and dried in a desiccator over $\mathrm{CaCl}_{2}$.

\section{Isolation of the glycopeptide from the cerumen}

The glycopeptide was extracted from the cerumen according to the procedure of Schiller et al. (1961). The samples were digested with papain (EC 3. 4. 4.10) in the presence of EDTA and cysteine at $65^{\circ} \mathrm{C}$ for $48 \mathrm{hr}$. The mixture was adjusted to $\mathrm{pH} 7.8$ and then digested with trypsin (EC 3.4.4.4) at $37^{\circ} \mathrm{C}$ for $48 \mathrm{hr}$ with simultaneous dialysis against $0.1 \mathrm{M}$ phosphate buffer, $\mathrm{pH}$ 7.8. The digested solution was deproteinized with $5 \%$ trichloroacetic acid in the cold, and the supernatant was dialyzed against several changes of cold deionized water for $72 \mathrm{hr}$. Then four volumes of alcohol containing $0.1 \%$ acetic acid and $1 \%$ potassium acetate were added in order to precipitate the glycopeptide. The precipitate was dried in a desiccator over $\mathrm{CaCl}_{2}$ and then dissolved in $5 \mathrm{ml}$ of the deionized water for the use of chemical analyses. 
Analytical procedures

Hexose was determined by the orcinol-sulfuric acid reaction of Winzler (1955 a) ; peptide by the Lowry method (1951) ; sialic acid by the diphenylamine reaction of Winzler (1955 b) ; fucose by the Gibbons reaction (1958); and sulfate by the method of Dodgson and Price (1962) ; respectively. Uronic acid measurement was also tried by the carbazole reaction of Bitter (1962). The separation and quantitative determination of glucosamine and galactosamine were carried out with a Hitachi KLA-3 Amino Acid Analyser, using a $20 \mathrm{~cm}$ column in citrate buffer of $\mathrm{pH} 5.28$ $(\mathrm{Na}: 0.35 \mathrm{~N})$. Neutral sugars were separated and identified by paper chromatography after hydrolysis in $1 \mathrm{~N} \mathrm{HCl}$ for $3 \mathrm{hr}$ at $100{ }^{\circ} \mathrm{C}$ in a sealed ample; Whatman filter paper No. 1 was used as a supporting medium; the solvent system was $\mathrm{n}$ - butanol - pyridine- $0.1 \mathrm{~N}$ $\mathrm{HCl}(5: 3: 2 \mathrm{v} / \mathrm{v} / \mathrm{v})$, Chromatogram obtained by descending paper chromatography, and double development techniques was stained with $\mathrm{AgNO}_{3}-\mathrm{NaOH}$ reagent.

\section{RESULTS AND DISCUSSION}

The glycopeptide content in the cerumen was $9.1 \mathrm{mg}$ per $\mathrm{g}$ of rough weight and $12.5 \mathrm{mg}$ per $\mathrm{g}$ of defatted dry weight, respectively. The preparation was subjected to analyses for hexose, peptide, sialic acid, fucose, sulfate, glucosamine, galactosamine and uronic acid; the results are summarized in Table 1. Hexose and peptide were main components, while uronic acid was scarcely detected. Both galactosamine and glucosamine were also found the former was more contained than the latter.

The consititution of the neutral hexose was studied by paper chromatography, as shown in Fig. 1. It was
TABLE 1

Analyses of the glycopeptide from cerumen ${ }^{\mathrm{a}}$

\begin{tabular}{lr}
\hline Hexose & 29.3 \\
Peptide & 48.1 \\
Sialic acid & 7.3 \\
Sulfate & 3.5 \\
Fucose & 1.5 \\
Galactosamine & 12.6 \\
Glucosamine & 1.7 \\
Uronic acid & 0.1 \\
\hline
\end{tabular}

a Expressed as percentage of weight.

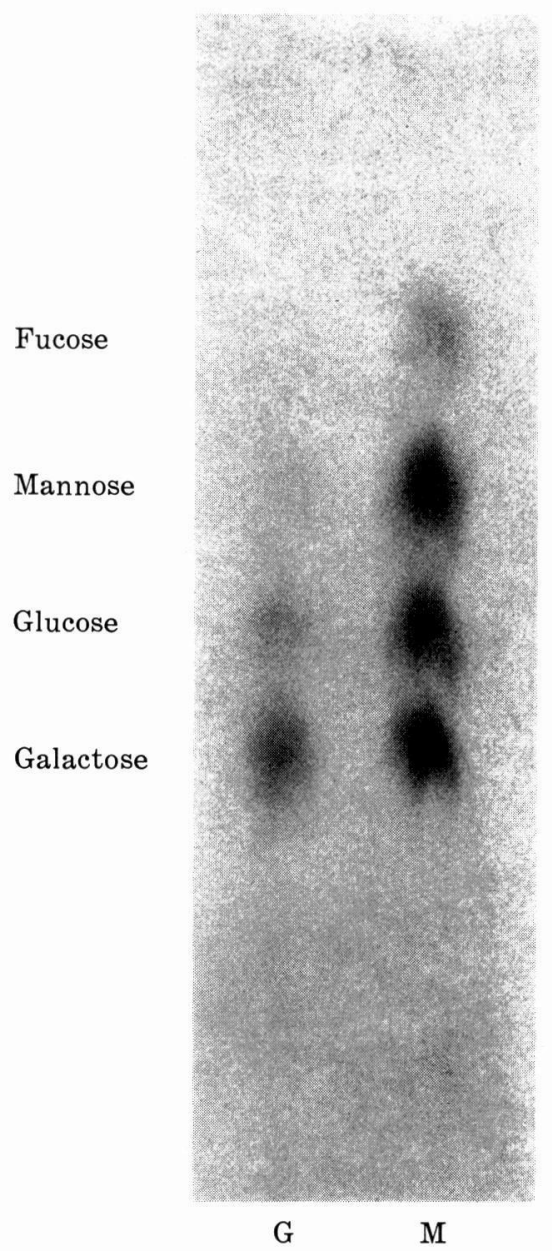

Fig. 1 Paper chromatogram of hydrolysate of glycopeptide from cerumen.

G : Glycopeptide from cerumen.

M : Mixture of fucose, mannose, glucose and galactose as a reference. 
found that the preparation possessed galactose and glucose as main components and only traces of mannose and fucose.

Although several glycopeptides were isolated from several human sources (Odin, 1958 ; Pusztai and Morgan, 1961 ; Endo et al., 1973), there are no comparative data concerning the glycopeptide from the human cerumen in the literature. Uronic acid was a little detected in the cerumen of the present study, while it was reported that mucous membrane of human paranasal air sinuses, human skin and rat cochlea contained certain amounts of uronic acid, respectively (Sato, 1966 ; Shetlar et al., 1972 ; Saito and Daly, 1970); these may probably show that the glycopeptide isolated by the authors is mainly derived not from skin itself in the external auditory meatus but from the secretion of the glands. Histochemical analysis has indicated that the cerumen is the combined secretion of the sebaaceous and the ceruminous glands in the external auditory meatus (Ham, 1974). Further purification of this material will surely be necessary, and accordingly it is in progress by the authors.

\section{REFERENCES}

Bitter, T. and Muir, H. (1962). A modified uronic acid carbazole reaction. Anal. Biochem., 4, 330-334.

Dodgson,K.S. and Price, R.G. (1962). A note on the determination of the ester sulphate content of sulphate polysaccharides. Biochem. J, 84, 106-110.

Endo, M., Tamura, S., Minakuchi, S., Ouchi,
H. and YôshizawA, Z. (1973). Isolation and identification of proteohyaluronic acid from a cyst of cystic mucoid degeneration. Clinica Chim. Acta, 47, 417-424.

GibBons, M. N. (1958). The determination of methylpentoses. Analyst, 80, 268-276.

HAM, A. W. (1974). In "Histology", pp. 973987. J. B. Lippincott, Philadelphia.

Lowry, O. H., Resebrough, N. J, FARr, A. L. and RANDAll, R. J. (1951). Protein measurement with Folin phenol reagent. J. biol. Chem., 193, 265-271.

ODIN, L. (1958). In "Symposium on the Chemistry and Biology of Mucopolysaccharides". pp. 234-244. J. and A. Churchill, London.

Pudztai, A. and Morgan, W.T.J. (1961). The isolation and properties of a sialomucopolysaccharide possessing blood-group $\mathrm{Le}^{\mathrm{a}}$ specificity and virus-receptor activity. Biochem. J., 78, 135-145.

SAITo,H. and DALY, J.F. (1970). Quantitative analysis of acid mucopolysaccharides in the normal guinea pig cochlea. Acta OtoLaryngol, 69, 333-340.

SATo, Y. (1966). Biochemical studies on acid mucopolysaccharides in paranasal mucous membrane in chronic sinusitis. Jap. J. Oto-Laryngol, 69, 1038-1064.

Schiller, S., Slover, G. A. and Dorfman, A. (1961). A method for the separation of acid mucopolysaccharides ; its application to the isolation of heparin. J. biol. Chem., 236, 983-990.

Shetlar, M. R., Shetlar, C. L., Chien, S. F., Linares, H. A., Dobrkovsky, M. and LARson, D. L. (1972). The hypertrophic scar. Hexosamine containing components of burn scars. Proc. Soc. exp. Biol. Med., 139, 544-547.

TANAKA, Y. (1967). Acid mucopolysaccharides and glycoproteins in the skin. J. Kurume med. Assoc., 30, 899-908.

WINZLER, R. J. (1955 a). In "Methods of Biochemical Analysis" (D. Glick, ed.), II, pp. 290-292, John Wiley Interscience, New York.

WINZLER, R. J. (1955 b). ibid, pp. 296-300. 